УДК 351.77:659.1

Віннікова I.I.

канд. економ. наук, дочент

ДВНЗ «Київський економічний університет імені Вадима Гетьмана»

Пономаренко I.B.

канд. економ. наук, доцент,

ДННУ «Академія фінансового управління»

Гребньов Г.М.

Національний технічний університет Украӥни «КПI»

\title{
ВПЛИВ ПОЛІТИКО-ПРАВОВОГО ФАКТОРУ НА РЕКЛАМУ ЛІКАРСЬКИХ ЗАСОБІВ
}

\author{
ВЛИЯНИЕ ПОЛИТИКО-ПРАВОВОГО ФАКТОРА НА РЕКЛАМУ \\ ЛЕКАРСТВЕННЫХ СРЕДСТВ
}

\section{THE IMPACT OF POLITICAL AND LEGAL FACTORS ON ADVERTISING OF MEDICINES}

В статті визначено роль політико-правового фактору та його вплив на рекламу лікарських засобів в Україні. Показано взаємозв'язок між рекламою лікарських засобів $i$ функціонуванням фармацевтичного ринку. Підкреслено роль фармацевтичного ринку як стимулюючого чинника вдосконалення здоров'я начії. Обтрунтовано, щзо фармачевтичний ринок $\epsilon$ відображенням соціально-економічного розвитку країни. Рекламу лікарських засобів розглянуто як ефективний інструмент впливу при вирішенні економічних $i$ сочіальних проблем. Особливу увагу присвячено забезпеченню населення Украйни якісними $i$ безпечними лікарськими засобами. Проаналізовано нормативно-правові аспекти реклами лікарських засобів. Визначено перелік вимог щзодо виробниитва $і$ контролю лікарських засобів з метою впровадження системи європейських стандартів якості. Систематизовано три напрями оцінки якості, безпеки та ефективності лікарських засобів. Розроблено класифікащію реклами лікарських засобів залежно від характеристик иільових аудиторій, завдань реклами, а також характеристик місиь доступу споживачів до лікарських засобів.

Ключові слова: реклама, реклама лікарських засобів, фармацевтичний ринок.

В статье определена роль политико-правового фактора и его влияние на рекламу лекарственных средств в Украине. Показана взаимосвязь между рекламой лекарственных средств и функиионированием фармацевтического рынка. Подчеркнута роль фармачевтического рынка как стимулирующего фактора улучшения здоровья начии. Обосновано, что фармацевтический рынок является отражением социальноэкономического развития страны. Реклама лекарственных средств рассмотрена как эффективный инструмент влияния при решении экономических и соииальных проблем. Особое внимание уделяется вопросам обеспечения населения Украины качественными и безопасными лекарственными средствами. Проанализированы нормативно-правовые аспекты рекламы лекарственных средств. Установлено перечень требований по производству и контролю лекарственных средств с иелью внедрения системь европейских стандартов качества. Систематизировано три направления оченки 
качества, безопасности и эффективности лекарственных средств. Разработана классификачия рекламы лекарственных средств, в зависимости от характеристик иелевых аудиторий, задач рекламы, а также характеристик мест доступа потребителей $\kappa$ лекарственным средствам.

Ключевые слова: реклама, реклама лекарственных средств, фармацевтический рынок.

The authors in the article touches the role of political and legal factors and its impact on the advertising of medicines in Ukraine. The relationship between the advertising of medicinal products and pharmaceutical market functioning are showed. Emphasizes the role of the pharmaceutical market as a stimulating factor in improving the health of the nation. Proved that the pharmaceutical market is a reflection of the socio-economic development. Advertising of medicines considered as an effective tool in dealing with the impact of economic and social problems are reviewed. Particular attention is paid to the problems of providing the population of Ukraine with quality and safety of medicines. Analyses the legal aspects of drug advertising. The list of requirements for the production and control of drugs for the purpose of the European quality standards introduction are detected. Systematizes three areas of assessment of quality, safety and efficacy of medicines. Develops the classification of drug advertising, which depending on the characteristics of the target audience, advertising objectives and characteristics of places consumers' access to medicines.

Key words: advertising, advertising of medicines, pharmaceutical market.

Вступ. Розгортання кризових явищ в економіці нашої країни з початком світової фінансово-економічної кризи зумовило поєднання внутрішніх суперечностей соціально-економічного розвитку країни 3 проявами глобальної кризи.

Для України вже тривалий час характерним $є$ загострення неузгодженості - протиріччя між капіталізацією економіки, прагненням до підвищення економічної ефективності та об'єктивної необхідності соціалізації економіки, доповнення економічного порядку таким соціальним порядком, який допомагав би вирішити й ключові проблеми економічного життя: забезпечення більш справедливого розподілу доходів і майна, проблему економічної влади й рівномірного розподілу шансів щодо розвитку особистості, витрат на соціальний захист, збереження здоров'я нації i купівельної спроможності щодо придбання лікарських засобів.

На виконання державної програми розвитку галузі активно впроваджується система забезпечення якості лікарських засобів, яка охоплює усі етапи обігу ліків, починаючи з їх створення до реалізації та застосування споживачем (фармацевтична розробка лікарського засобу, належна лабораторна, клінічна, виробнича, дистриб'юторська, фармацевтична практики).

Фармацевтичний ринок України - одна із стратегічно-важливих галузей для розвитку нашої держави. Підвищений інтерес до нього викликаний економічними, соціальними і навіть політичними факторами, бо саме через 
цей ринок забезпечується попит на лікарські препарати, а значить, і захист здоров'я населення. Попит на лікарські препарати, своєю чергою має підтримуватись високим рівнем життя людей, їхньої платоспроможності, а також адекватною структурою і обсягом відповідної продукції [5, 75$]$.

Сьогодні фармацевтична галузь перетворилася в одну з перспективних галузей світової економіки, яка здійснює значний вплив на розвиток соціально-економічних процесів.

Сучасний етап розвитку фармацевтичного ринку України характеризується, з одного боку, все більшим розвитком недержавних форм власності, з іншого - ефективним використанням державного регулювання та контролю.

Для України, як і для багатьох країн світу, фармацевтичний ринок $є$ стимулюючим чинником вдосконалення здоров'я нації і перспективною сферою бізнесу. Україна має всі умови для того щоб фармацевтичний ринок розвивався.

На фармацевтичному ринку реклама лікарських засобів $\epsilon$ інструментарієм, який допомагає фармацевтичним підприємствам просувати свої товари на ринок.

Питання становлення та розвитку теорії рекламних комунікацій вивчали у своїх працях такі зарубіжні автори, як: Н.Андрсон, Н.Гованні, Я.Гордон, Е.Гуммесон, Д.Джоббер, Ф.Котлер. Серед вітчизняних вчених у цьому напрямку працювали А.Ф. Павленко, А.В. Войчак, В.П. Пилипчук, І.В. Лилик,І.Л.Решетнікова, Т.І. Лук'янець, Т.О. Примак, Е.В. Ромат.

Більшість цих вчених приділяло увагу рекламі, рекламним комунікаціям, але питання класифікації реклами лікарських засобів залежно від цільових аудиторій, завдань реклами, систематизації рівнів контролю якості і безпеки не було визначено.

В умовах ринкової економіки підвищується роль реклами, що обумовлено загостренням конкурентної боротьби на фармацевтичному ринку.

Ніхто не ставить під сумнів необхідність використання реклами на ринку лікарських засобів.

Але швидкий розвиток фармацевтичного ринку, поява все нових можливостей, зростання конкуренції галузі вимагає переосмислення підходів до реклами на ринку лікарських засобів.

Постановка завдання. Метою статті є дослідження впливу політикоправового фактору на рекламу лікарських засобів. Науковими завданнями, які ставляться під час дослідження, $\epsilon$ визначення специфіки реклами лікарських засобів, дослідження вимог стандартів якості на фармацевтичному ринку та розроблення класифікації реклами лікарських засобів.

Проблема збільшення рекламної активності на фармацевтичному ринку стає все більш важливою по мірі виникнення необхідності пошуку нових, 
більш ефективних рекламних можливостей і появи в зв'язку з цим прикладів недобросовісної реклами.

Дослідження правового аспекту реклами лікарських засобів не втрачає своєї актуальності оскільки лікарські засоби є специфічним товаром.

I хоча вплив політичного курсу на окремі види маркетингової діяльності не завжди піддається точній оцінці, ми розглянемо всі аспекти реклами лікарських засобів.

Методологія. Теоретичною і методологічною основою статті є сучасна теорія і практика маркетингу і реклами, закони та нормативні акти України 3 питань економіки та реклами.

Дослідження грунтується на загальнонауковому комплексі методів: аналізу, синтезу, порівняння та аналогій.

Результати дослідження. Будь-яка економічна система працює краще, коли є законодавчі акти, що регулюють ту чи іншу діяльність. Ретельно розроблені регулятивні акти заохочують конкуренцію та забезпечують сприятливі умови для розвитку ринку товарів і послуг. Тому уряд будь-якої країни проводить державну політику, спрямовану на регулювання підприємницької діяльності. Для цього приймаються спеціальні закони i постанови, які обмежують бізнес на благо суспільства в цілому [4,c.109-110].

Останнім часом у всьому світі постійно зростає роль держави у регулюванні підприємницької діяльності. В Україні затверджено велику кількість законів, що стосуються конкуренції, принципів добросовісної торгівлі, захисту навколишнього середовища, безпечності товарів, упаковки, маркування, правдивості реклами,ціноутворення та інших важливих галузей економіки.

Але поряд з питаннями економічної стабільності і економічної безпеки постає питання регулювання реклами лікарських засобів.

Розвиток ринкової економіки в Україні супроводжується об'єктивним ростом у сфері рекламних послуг. Однак, при всій прибутковості і виправданості цієї галузі бізнесу, рекламні послуги здійснюють негативний побічний вплив як на психологію суспільства, так і на впровадження дійсно нових i, як наслідок, малопотужних технологій і товарів, обмежуючи поле конкурентів розмірами відповідних грошових уливань.

Сучасна реклама є спеціальною формою комунікації. Реклама сьогодні інструмент впливу при вирішенні економічних, політичних, соціальних проблем. Вона проникла в усі сфери людського існування. По суті, реклама це інформація. Вона виконує інформативну функцію та формує знання людини [8, с.11].

Реклама лікарських засобів $є$ інструментом корисного інформування потенційних споживачів. Реклама лікарських засобів зазнає значного впливу 
політичного середовища. Закони, державні інструкції здійснюють тиски i обмежують їі.

Ще один фактор - висока вартість реклами, який стримує можливості просування ліків більшістю вітчизняних виробників, й, водночас, $\epsilon$ конкурентною перевагою потужних транснаціональних фармацевтичних компаній. Оскільки комерційна реклама є платною послугою, то в кошторис кожної одиниці товару включається вартість реклами, а це в свою чергу впливає на вартість одиниці товару (тобто лікарського засобу).

Тому рекламу лікарських засобів собі можуть дозволити тільки потужні фармацевтичні компанії.

Аналіз рекламної діяльності провідних закордонних виробників свідчить про те, що більшість рекламованих лікарських засобів не $є$ останніми розробками фармацевтики. Більш того, багато з них не входять у сучасні схеми та стандарти лікування. Це $є$ фактом того, що сьогодні Україна розглядається багатьма західними виробниками як перспективний ринок для збуту застарілих ліків, які вже не витримують конкуренції на розвинутих фармацевтичних ринках.

3 іншого боку, ми спостерігаємо ситуацію, коли багато споживачів не в змозі придбати дійсно ефективні ліки, що рекламуються. Тому на ринку 3'являються конкуренти-замінники ефективних лікарських засобів.

Ця ситуація яскраво відбивається й у показниках стану здоров'я населення України.

Незадовільний стан здоров'я населення та низька тривалість життя в Україні лишається однією з їі медико- та соціально-демографічних проблем. Україна за часткою населення у віці понад 60 років входить до тридцятки найстаріших держав світу, посідаючи наразі 25-26 місце (яке вона поділяє 3 Норвегією) у рейтингу країн світу за цим показником [9].

Слід зазначити, що проблема забезпечення населення України лікарськими засобами і доведення інформації до споживачів про ці лікарські засоби є важливою. На жаль, в Україні склалася тенденція щодо самолікування. Тому дуже часто, отримавши 3 реклами інформацію про лікарський засіб, споживачі приймають лікарські засоби не проконсультувавшись з лікарем.

Ще одна тенденція - відсутність традицій дбайливого ставлення людей до здоров’я. Людина звертається до лікаря, як правило, тоді, коли захворювання переходить уже в хронічну форму. Звідси дуже високі витрати i держави й населення на лікування, адже відомо, що хворобу дешевше попередити, ніж лікувати [5, с.92-93].

Останніми роками чітко визначились нові тенденції в асортиментній політиці, методології реклами лікарських засобів вітчизняними виробниками. Основні з них такі: 
- різке збільшення брендованих генеричних препаратів;

- більш активне використання різноманітних інструментів просування (зовнішня служба - при просуванні, переважно рецептурних препаратів, акції для аптек тощо);

- збільшення активності щодо прямої реклами, спрямованої на кінцевого споживача;

- активізація окремих напрямків іміджевої та соціально спрямованої реклами.

Це сприяло підвищенню поліпшення якості промоцій їх та рекламних зусиль вітчизняними виробниками лікарських засобів, що поступово змінює вектор конкуренції з цінового на інтегровані маркетингові комунікації.

Регулювання державою реклами лікарських засобів $є$ захист споживача від недобросовісної ділової практики. Завдяки регулюванню реклами лікарських засобів зменшилися випадки недобросовісної реклами і споживачі по-перше, не витрачають кошти на непотрібні їм ліки, а по-друге - не купують неякісні препарати, які також дуже часто рекламуються [7].

Деякі фармацевтичні підприємства за відсутності державного контролю могли б розгорнути виробництво ліків низької якості, підкріплюючи їх неправдивою рекламою, і вводити споживачів в оману, використовуючи привабливу упаковку та низьку ціну.

Діяльність рекламних фірм та організацій на ринку України контролюється і регламентується державою і громадськістю.

До цього зобов язують Конституція України (ст. 42), Положення Міжнародного Кодексу рекламної практики, Правила професійної етики в рекламі, розроблені Спілкою рекламістів в Україні за дорученням Антимонопольного комітету. Правилами необхідно керуватись на основі законодавчого забезпечення рекламної діяльності в Україні.

Закони України "Про лікарські засоби", "Про рекламу", "Про захист прав споживачів”, Закони України "Про телебачення та радіомовлення”, “ Про друковані засоби масової інформації (пресу) в країні", Закон України "Про захист від недобросовісної конкуренції”, Закон України “Про мови", Постанова ВР України "Про порядок введення в дію Закону України "Про рекламу" та інші.

Аналіз чинного українського законодавства щодо реклами лікарських засобів показав, що Конституція України, як основний закон держави у статті 42 визначає: «Держава захищає права споживачів, здійснює контроль за якістю і безпечністю продукції та усіх видів послуг і робіт, сприяє діяльності громадських організацій споживачів»[1].

Тобто держава гарантує, що всі лікарські засоби, які є на ринку України мають бути якісними і безпечними для здоров'я. 
Виходячи 3 цього, систему забезпечення лікарськими засобами фармацевтичного ринку України доцільно розділити на три напрями щодо контролю якості лікарських засобів (таблиця).

Таблиця

Рівні контролю якості лікарських засобів

[Джерело: власні дослідження авторів]

\begin{tabular}{|l|l|}
\hline I рівень контролю & $\begin{array}{l}\text { - експертна оцінка та реєстрація лікарських } \\
\text { засобів }\end{array}$ \\
\hline II рівень контролю & $\begin{array}{l}\text { виробництво лікарських засобів та система } \\
\text { забезпечення ліками }\end{array}$ \\
\hline III рівень контрою & $\begin{array}{l}\text { державний контроль якості лікарських } \\
\text { засобів }\end{array}$ \\
\hline
\end{tabular}

На першому рівні (експертна оцінка) - Державний фармакологічний комітет MO3 України приймає документацію від заявника, проводить експертну оцінку якості та систему реєстрації лікарських засобів i, нарешті, вирішує питання допуску лікарських засобів на фармацевтичний ринок України. Державне підприємство "Науково-експертний фармакопейний центр" MO3 України дає експертну оцінку якості лікарських засобів.

На другому рівні (виробництво) - Державний департамент з контролю за якістю, безпекою та виробництвом лікарських засобів і виробів медичного призначення MO3 України контролює виробництво лікарських засобів та забезпечує ліками фармацевтичний ринок України.

На третьому рівні (продаж)- Державна інспекція 3 контролю за якістю лікарських засобів МО3 України контролює якість лікарських засобів за межами заводу-виробника в медичних установах, аптеках, на оптових складах, в оптово-роздрібній торгівлі.

Система реєстрації ліків вимагає аналізу ідеології й методології використання їх (такий порядок існує у світовій практиці) та відпрацювання відповідних рекомендацій і проектів наказів Міністерства охорони здоров'я України щодо застосування населенням ефективних лікарських засобів високої якості.

Оцінка якості, безпеки та ефективності препаратів здійснюється через процедуру їх державної реєстрації, якій передує експертиза матеріалів, що декларують відповідні властивості лікарського засобу та рекомендації щодо його застосування.

На сьогодні суттєво збільшено обсяг вимог щодо досліджень у галузі фармакології, токсикології, фармації та у хіміко-фармацевтичних напрямах; більше уваги приділяється розробці проектів та інструктивно-регламентуючих документів i рекомендацій, пов'язаних зі створенням, вивченням та впровадженням лікарських засобів, підготовкою необхідних документів для 
подальшої реєстрації, розробкою рекламної стратегії, спрямованої на захист фармацевтичного ринку України від недоброякісної продукції.

Реклама лікарських засобів $\epsilon$ одним із напрямків інформаційного забезпечення стабільного фармацевтичного ринку i повинна відповідати правовим актам країни та міжнародним принципам у сфері обігу ліків з метою створення гарантій їх ефективності та безпеки.

Залежно від статусу відпуску лікарські засоби поділяються на:

- лікарські засоби, які відпускаються та розповсюджуються тільки за рецептом лікаря;

- лікарські засоби, які відпускаються та розповсюджуються без рецепту.

Рішення, щодо засобів поширення рекламної інформації приймають, як правило, з урахуванням характеристик кожного із лікарських засобів, а також приналежності лікарського товару до рецептурних чи без рецептурних препаратів.

Рецептурні препарати рекламуються лише у спеціалізованих друкованих засобах інформації, що розраховані на медичних та фармацевтичних фахівців, i, звичайно, на семінарах та конференціях медпрацівників; без рецептурні ліки дозволяється рекламувати, послуговуючись найширшим арсеналом засобів масової інформації.

Головним нормативно-правовим документом, який визначає засади рекламної діяльності в Україні, регулює відносини, що виникають у процесі виробництва, розповсюдження та споживання реклами - є Закон України «Про рекламу» [2].

Згідно розділу 3 «Особливості рекламування деяких видів товару» дозволяється лише реклама без рецептурних препаратів. Лікарські засоби, які відпускають тільки за рецептом лікаря внесено до переліку заборонених до реклами лікарських засобів. Реклама лікарських засобів має містити рекомендації щодо ознайомлення з інструкцією, та вимогу про необхідність консультації з лікарем.

3 огляду на це, ми можемо класифікувати рекламу лікарських засобів, яка розподіляється залежно від характеристик цільових аудиторій, завдань реклами, а також характеристик місць доступу споживачів до лікарських засобів (рисунок). 


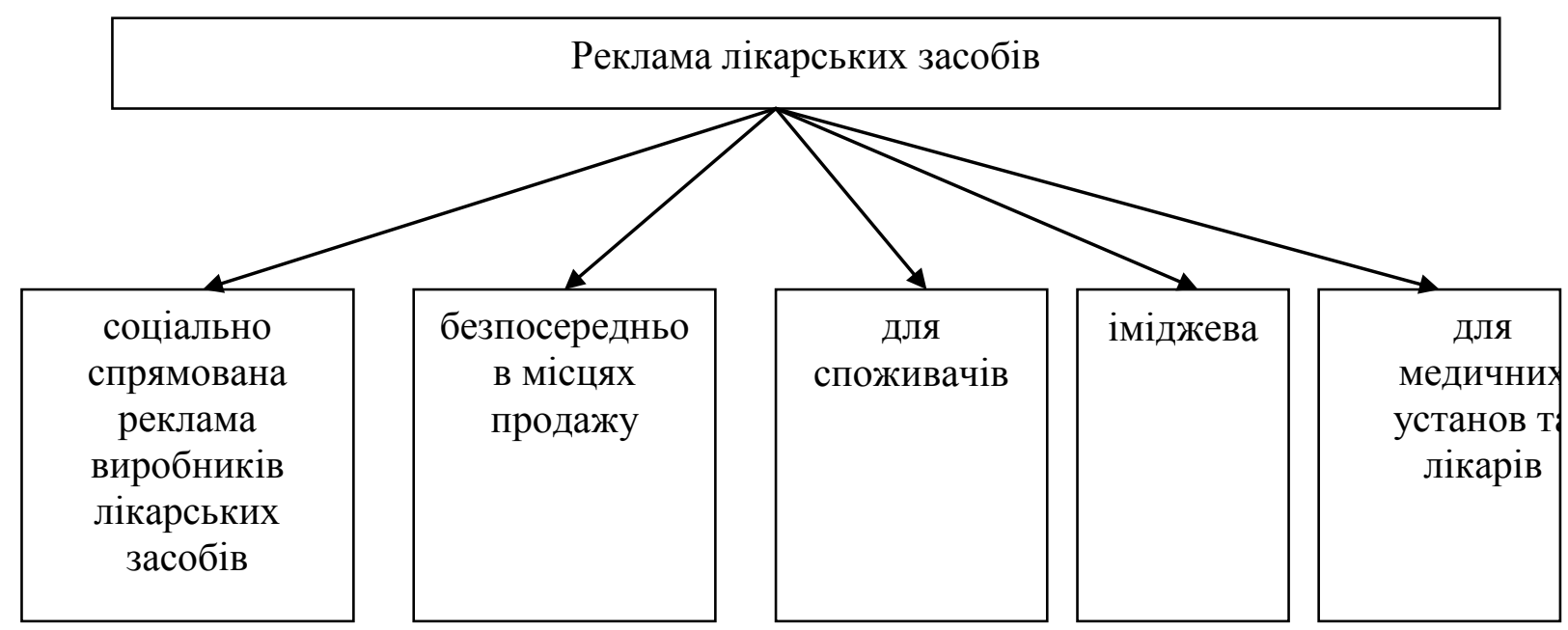

Рисунок. Класифікація реклами на ринку лікарських засобів

[ Джерело: власні дослідження авторів]

Регламентація реклами лікарських засобів здійснюється за допомогою низки державних законів та актів. Дозвіл на розміщення інформації, яка може міститися в рекламі лікарських засобів, що реалізуються громадянам за рецептами лікарів, видається Фармакологічним Комітетом Міністерства охорони здоров я України. Зміст реклами регулюється Законом України «Про рекламу», а також Законом України «Про лікарські засоби».

Згідно з українським законодавством рекламуванню підлягають тільки зареєстровані лікарські засоби.

Рекламувати лікарський засіб підприємство може тільки тоді, коли отримає дозвіл, затверджений Головою Комітету: на різні лікарські форми реклами одного лікарського засобу видається окремий дозвіл на підставі окремої експертизи.

Рішення про погодження рекламної інформації видається заявнику не пізніше 30 днів після подання до Комітету заяви та необхідних документів. У разі незгоди заявника з експертним висновком щодо рекламної інформації він може оскаржити цей висновок до президії Комітету.

Реклама лікарських засобів не повинна мотивувати виключність будьякого препарату 3 точки зору гарантованості ефекту нешкідливості та відсутності побічної дії, без альтернативності його застосування щодо інших існуючих лікарських засобів, справляти враження, що за умов його застосування медична консультація фахівця не потрібна, а відмова від прийому препарату спричинить шкоду для здоров `я, містити посилання на терапевтичні ефекти ліків стосовно захворювань, які не піддаються або важко піддаються лікуванню, а також на рекомендації науковців, медичних 
працівників та інших категорій осіб, які у зв`язку 3 своїм професійним статусом можуть вплинути на вживання препарату, вводити в оману щодо властивостей лікарського засобу.

Міністерство охорони здоров`я України у встановленому порядку у випадках порушення зазначених вимог вживає необхідних заходів відповідно до законодавства щодо запобігання недобросовісної реклами та іiі припинення.

Головним нормативним документом, що регулює якість лікарських засобів, є Державна Фармакопея України (ДФУ), опублікована у вересні 2001 p. окремим збірником, в якому зібрано найголовніші державні стандарти якості лікарських засобів.

Уведення в дію Державної Фармакопеї України є одним 3 важливих елементів впровадження системи європейських стандартів якості лікарських засобів (GMP) і $є$ однією 3 необхідних передумов для переходу нашого медичного забезпечення на якісно новий рівень.

Державна Фармакопея України (ДФУ) — це правовий документ, що містить загальні вимоги до ліків, ФС (монографії), а також методики контролю їх якості (Закон України «Про лікарські засоби», ст. 2) [3].

Україна єдина серед країн колишнього СРСР має свою національну Фармакопею - ДФУ 1-го видання (ДФУ 1), яку введено в дію 31 жовтня 2001 р. Розробником ДФУ є Державне підприємство «Український науковий фармакопейний центр якості лікарських засобів».

Фармакопея має законодавчий характер. Ї̈̈ вимоги, що висуваються до лікарських засобів, є обов'язковими для підприємств і установ України незалежно від їх форм власності, що виробляють, зберігають, контролюють, застосовують лікарські засоби [6].

Уведення в дію Державної Фармакопеї України є одним з важливих елементів впровадження системи європейських стандартів якості лікарських засобів (GMP) і $є$ однією 3 необхідних передумов для переходу нашого медичного забезпечення на якісно новий рівень.

GMP (GOOD Manufacturing Practice - (Належна виробнича практика) це перелік вимог до виробництва і контролю лікарських засобів (ЛЗ), навчання і кваліфікації персоналу, приміщень, обладнання, інгредієнтів, зберігання і транспортування.

Найважливішими елементами GMP є відповідність всієї технологічної і контрольної документації на підприємстві змісту реєстраційного досьє на відповідний препарат, жорсткий контроль за дотриманням правил виробництва лікарських засобів вимогам GMP, забезпечення ефективними безпечними i якісними лікарськими засобами, здоров'я пацієнта, забезпечення національної безпеки. Додержання вимог GMP є обов'язковим для фармацевтичних фірм - виробників більшості країн світу, а сертифікація 
за GMP - необхідною умовою ліцензування лікарських засобів, їх реєстрації та дистрибуції.

Нині немає єдиного стандарту GMP, прийнятого в усьому світі. Крім вимог Європейського стандарту, існує кілька інших інструкцій , включаючи вимоги FDA до продукції, що продається у США, австалійський код GMP i японські стандарти. Для будь-якої країни, члена Європейського Союзу, обов'язковими $є$ принципи функціонування цієї спільноти. Деякі з країн Центральної та Східної Свропи використовують ЄC-GMP як стандарт для порівняння.

Беручи до уваги той факт, що для більшості країн не можливим $є$ досягнення повної відповідності стандартам GMP, Всесвітня організація охорони здоров'я (BОO3) опублікувала перелік вимог GMP, що формулюють мінімум стандартів, необхідних для охорони здоров'я, добробуту та безпеки пацієнтів.

Висновки. Розвиток ринкової економіки в Україні супроводжується об'єктивним ростом у сфері рекламних послуг. Однак, при всій прибутковості і виправданості цієї галузі бізнесу, рекламні послуги здійснюють негативний побічний вплив як на психологію суспільства, так і на впровадження дійсно нових i, як наслідок, малопотужних технологій і товарів, обмежуючи поле конкурентів розмірами відповідних грошових уливань.

Довіряти привабливим і яскравим щитам та роликам - справа особиста, а от купувати ліки без консультації фахівців не слід, обов'язково треба порадитися з лікарем.

Реклама лікарських засобів не повинна мотивувати виключність будьякого препарату 3 точки зору гарантованості ефекту нешкідливості та відсутності побічної дії, без альтернативності його застосування щодо інших існуючих лікарських засобів. Справляти враження, що за умов його застосування медична консультація фахівця не потрібна, а відмова від прийому препарату спричинить шкоду для здоров я,містити посилання на терапевтичні ефекти ліків стосовно захворювань, які не піддаються або важко піддаються лікуванню, а також на рекомендації науковців, медичних працівників та інших категорій осіб, які у зв язку з своїм професійним статусом можуть вплинути на вживання препарату, вводити в оману щодо властивостей лікарського засобу.

Наукова новизна отриманих результатів полягає в тому, що визначено роль держави в регулюванні реклами лікарських засобів, перелік вимог щодо виробництва і контролю лікарських засобів, систематизовано три напрями оцінки якості, безпеки та ефективності лікарських засобів. Розроблено класифікацію реклами лікарських засобів залежно від характеристик цільових аудиторій, завдань реклами, а також характеристик місць доступу споживачів до лікарських засобів. 
Отримані результати можуть бути використані у практиці вітчизняних підприємств при рекламуванні лікарських засобів, слугувати теоретичним підгрунтям для подальших досліджень із удосконалення процесу регулювання державою реклами лікарських засобів.

Також, висновки і пропозиції надані в статті можуть бути корисними пересічним громадянам при виборі і придбанні лікарських засобів.

\section{Література:}

1. Конституція України = Конституция Украины: [зі змін. та допов., внесеними Законом України від 1 лют. 2011 р. № 2952-VI]. - Х. : Фактор, 2011. - 118 с. - (Серія «Бібліотека законодавства»).

2. Про рекламу [Електронний ресурс]: закон України [прийнято Верхов. Радою 3 липня 1996 р. № 270/96-BP]. - Режим доступу: http://zakon4.rada.gov.ua/laws/show/270/96$\% \mathrm{D} 0 \% \mathrm{~B} 2 \% \mathrm{D} 1 \% 80$

3. Про лікарські засоби [Електронний ресурс] : закон України [прийнято Верхов. Радою 4 квітня 1996 p. № 123/96-BP]. - Режим доступу : http://zakon4.rada.gov.ua/laws/show/123/96-\%D0\%B2\%D1\%80

4. Армстронг Г. Маркетинг. Загальний курс / Г. Армстронг, Ф. Котлер. - М.: Видавничий дім «Вільямс», 2001. - 608 с. - (5 видання).

5. Віннікова I. І. Рекламна діяльність фармацевтичних підприємств : дис. канд. ек. наук : 08.06.01 / Віннікова І. І. - К.: КНЕУ, 2006. - 228 с.

6.Державна Фармакопея України / Державне підприємство «Науково-експертний фармакопейний центр». - 1-е вид., доп. 4. - Харків: Державне підприємство «Український науковий фармакопейний центр якості лікарських засобів», 2011. - 536 с.

7. Кісельова О. Питання регулювання реклами лікарських засобів у пресі / О. Кісельова. // Щотижневик «АПТЕКА». - 2010. - №38 (759). - С. 80-82.

8. Ромат Є. В. Реклама в системі маркетингу: [Навч.посіб.] / Є. В. Ромат. - Київ: Студцентр, 2008. - 608 с.

9. World Population Prospects. The 2013 revision. Key Findings and Advance Tables [Електронний ресурс]. http://esa.un.org/wpp/documentation/pdf/WPP2012_\%20KEY\%20FINDINGS.pdf 